\title{
UNIVERSITYOF
}

FORWARD

THINKING

WESTMINSTER ${ }^{\text {用 }}$

WestminsterResearch

http://www.westminster.ac.uk/westminsterresearch

\section{Being Taught by Biesta}

\section{Charles, $\mathbf{M}$.}

This is an Accepted Manuscript of an article published by Taylor \& Francis in Pedagogy, Culture \& Society in 2016.

The final, definitive version is available from the publisher:

http://dx.doi.org/10.1080/14681366.2016.1160672

(c) Taylor \& Francis Inc.

The WestminsterResearch online digital archive at the University of Westminster aims to make the research output of the University available to a wider audience. Copyright and Moral Rights remain with the authors and/or copyright owners.

Whilst further distribution of specific materials from within this archive is forbidden, you may freely distribute the URL of WestminsterResearch: ((http://westminsterresearch.wmin.ac.uk/)).

In case of abuse or copyright appearing without permission e-mail repository@westminster.ac.uk 
Matthew Charles

English Literature and Cultural Studies, University of Westminster, London, UK

Email: m.charles1@westminster.ac.uk

\section{Being Taught by Biesta}

The Beautiful Risk of Education, Gert J. J. Biesta, Paradigm, 2013, 178 pp., £29.99 (paperback), ISBN 978-1-61205-027-0

\section{Introduction}

What are we to do with the writing of Biesta? Raising the same question in relation to Jacques Rancière, in a 2010 study co-authored with Charles Bingham, Gert J. J. Biesta takes the writer of 'a short, disparaging review of ...The Ignorant Schoolmaster' to task for "schooling" Rancière on the inadequacies of the book reviewed (Biesta \& Bingham 2010, 145-148). Readers of Biesta cheering on from the sidelines at this point are placed in an uncomfortable double bind if they are to take this suggestion seriously when reviewing his own work. ${ }^{1} \mathrm{We}$ are not, Biesta and Bingham $(2010$, 148) suggest, to police interpretations like a vigilant schoolmaster in possession of superior knowledge but rather "proceed as a child who looks forward to the sound of the bell' and to 'speak as if truant'.

As demonstrated by Biesta's recent trilogy of books on education, Beyond Learning: Education for a Human Future (2006), Good Education in an Age of Measurement (2010a) and The Beautiful Risk of Education (2013), the consistent strength of his writing is the lucidity and generosity with which difficult philosophical ideas are expressed: a genial tone of conversational intimacy guides the reader through the turns of the argument and around the community of scholars engaged with, and a largely jargon-free exposition of the thinkers under discussion ensures an enviable clarity. Biesta's writing gently persuades, rather than cajoles, intimidates or confronts its reader in any schoolmasterly fashion, and the popularity of his work is in part attributable to such an inclusive and humanistic approach, which serves a vital function in mediating between theoretical discourse and educational practice.

His latest book, The Beautiful Risk of Education, assembles a collection of philosophical interlocutors - including Levinas, Derrida, Rancière and Arendt - to articulate what, he insists $(2013,146 \& 1)$, 'many teachers know but', because 'it is not fashionable to argue that education ought to be risky', are 'increasingly being prevented from talking about'. 
Together with Beyond Learning and Good Education in an Age of Measurement, this constitutes a theory of education, Biesta writes, containing ideas dating back to the late 1990s.

The author has in the intervening decades become justifiably established as one of the central figures in the philosophy of education and for this reason, as well as the fact that many of its chapters are based on previously published articles, much in The Beautiful Risk may already be familiar to readers of this journal. That earlier material has been reworked into a collection of chapters on key educational topics - Creativity, Communication, Teaching, Learning, Emancipation, Democracy and Virtuosity - addressed from the perspective of what Biesta thematizes as the necessary and positively conceived 'weakness' of education. Insisting that education can only authentically operate through connections whose weakness necessarily involve the risk of unexpected, unintended and unpredictable outcomes, The Beautiful Risk argues that were these connections to become risk-free, the processes involved could no longer be identified as educational.

One way of approaching Biesta's writing would therefore be to understand it as an educational event of the kind it theorizes, one in which what its readers experience is not transmitted as teachings nor some kind of theoretical doctrine, but rather through a philosophical opening upon such knowledge revealed through the dialogic mediation of the teacher. Such an approach is suggested by Biesta's own descriptions of how writing it 'taught me the very lesson that this book is about: that any act of creation (including education) is at best a dialogue between one's intentions and the material one works with...' (xi), how these ideas are "no more than "beginnings" in the Arendtian sense of the word' (one of Biesta's central claims is that education must be concerned with 'the ways in which new beginnings and new beginners come into the world' (4) as subjects), and they 'need to be taken up by others in ways that are necessarily beyond my control and my intentions ...in other words, they need to be "risked"...' (xi).

To approach Biesta's writing as an act of teaching, in fidelity to his own theory of education, therefore requires us to consider what is risked and what is made safe in his use of philosophical figures to articulate that which he claims many teachers already know about the weakness of education; to ask, that is, what function Biesta's own articulation plays in such teaching. This consideration might begin by attending more closely to the problems and criticisms that have troubled the reception of this philosophical discourse itself but which are passed over in Bieta's exposition, not in order to insist one must always "teach the conflicts" so much as to consider to what extent not teaching the conflicts in this instance risks - or doesn't risk - opening up or closing down the possibility of educational dialogue. 


\section{Teaching as First Ethics?}

The philosophy of Emmanuel Levinas, for example, plays a central role within this book and Biesta's writing more generally and has provided a rich source of inspiration for many other educational theorists, especially in the last 15 years. Much of this has, as the philosopher Stella Sandford $(2000,2)$ noted, 'given rise to an unusually sympathetic body of literature': an 'immanentism which would inoculate it against serious critique' and that for this reason does not always serve his philosophy well. Levinas's thought is concerned with the development of an ethics of subjectivity whose significance for education, Biesta argues, is related to the articulation of a domain of subjectification that, along with qualification and socialization, constitutes education's primary function. Levinas does not postulate the subject as a metaphysical being but is concerned with how subjectivity exists and especially the way it is always already engaged in an ethical and intersubjective relationship - characterized as one of infinite and unconditional responsibility - with the Other (19). Subjectivity is therefore always an ethical event, Biesta argues, in which one feels compelled to take on a responsibility 'to do justice to ... what is excluded and forgotten .... an affirmation ...of the otherness of who and what is other' (38). Similarly, one of the primary purposes of education, Biesta claims, is oriented towards the possibility of subjectivity as an ethical event that might be experienced through the intervention of otherness but which cannot be some thing to be programmed or produced (22). For this reason, education must always remain open, risky and weak. It is this concern with alterity that has made Levinasian ethics - and the 'ethical turn' within postmodern philosophy more generally - so attractive not only to Biesta but many working within educational theory.

The same concern that motivates this interest also demands an acknowledgement of how Levinas has been criticized by some for characterizing otherness in his earlier work in ways that may be problematic. In sections of Time and the Other (1987b, 85-94) and Totality and Infinity (1979, 154-158), for example, Levinas infamously identifies otherness with the feminine as the absolutely contrary, a perspective which - as Simone de Beauvoir $(2010,6)$, Gayatri Chakravorty Spivak (1993, 166; 2012, 292) and many others have pointed out engenders the Levinasian subject as masculine or male and, given the erotic nature of this relationship, heterosexual. While Levinas's subsequent shift towards a notion of the neighbour in Otherwise Than Being (1998) does permit a role for the feminine beyond the bearer of sexual difference for the masculine experience of alterity, it does so, Catherine Chalier $(1982,45)$ reminds us, only by problematically identifying it with the figure of maternity. 
The title and central idea behind The Beautiful Risk of Education was inspired, Biesta acknowledges (xi), by John D. Caputo's $(2006,60)$ use of Levinas to develop of a weak theology of the event, specifically the latter's description, in Otherwise than Being or Beyond Essence $(1998,120)$, of communication with the Other as 'an adventure of a subjectivity ...possible only in sacrifice ...transcendent only as a dangerous life, a fine [or beautiful, beau] risk to be run'. Biesta does not reference Sharon Todd's (2003a) earlier exposition of this idea and its applicability to education in her excellent article 'A Fine Risk to be Run? The Ambiguity of Eros and Teacher Responsibility' - subsequently expanded in Chapter 3 of her Learning with the Other: Levinas, Psychoanalysis, and Ethical Possibilities (2003b) - which is a shame not least because Todd's discussion does engage with the shifts and ambiguities in Levinas's own thinking about the Other, transcendence and the feminine, as well as suggesting more concretely what risks such encounters might involve.

Similarly, while Biesta recognizes that Levinas's philosophy poses a challenge to Western thought's privileging of consciousness, it should also be acknowledged that Levinas's account of alterity (and the philosophical conceptions of the face and of transcendence it is grounded in) has been accused by Robert Bernasconi (1992), Howard Caygill (2002), Andrew McGettigan (2006a, 2006b) and others of privileging the perspective of the Judeo-Christian tradition against that of others outside of 'the West'. The Beautiful Risk draws on Levinas's $(1979,51)$ account of revelation, for example, to emphasize the significance of teaching within the educative relationship, as that in which 'I receive from the other "beyond the capacity of the I" - which not only means "to have an idea of infinity" but also means "to be taught" (50). In an educational context, this implies we must resist the prevailing dominance of constructivist accounts of learning - in which the teacher 'is there to facilitate students' learning rather than to teach them a lesson' (57) - and insist that 'the idea of teaching, if it is to have any meaning beyond the facilitation of learning, needs to come up with a notion of "transcendence"" (56). Biesta (2015a, 2015b) has subsequently developed this position on teaching further in essays that draw on Levinas's essay 'Revelation in the Jewish Tradition' and Wilhelm Dilthey's formulations of Geisteswissenschaft or the Humanities.

This transcendence 'that reveals itself in a dimension of height' is in Totality and Infinity $(1979,155)$ clearly distinguished from the Other identified with feminine alterity, who is said to possess, in contrast, a 'language without teaching' (cf. McGettigan 2006a, 59). The transcendent dimension of the relationship between revelation and teachings is grounded in what Levinas (1991, 160) calls 'the Sacred History that forms the heart of the Judaic-Christian world'. It is a history, McGettigan (2006b, 17) observes, book-ended by the Judaic teachings 
or instructions of the Talmud and modern (neo-Kantian) formulations of Geisteswissenschaft or the Humanities rooted in the centrality of philosophical teachings or doctrine [Lehre]. Levinas $(1991,160)$ therefore infamously speaks of the 'arrival on the historical scene of those underdeveloped Afro-Asiatic masses who are strangers' to this Sacred History. While Levinas (1987a, 88) describes 'an orientation which leads the Frenchman to take up learning Chinese instead of declaring it to be barbarian (that is, bereft of the real virtues of language)', this relationship to the culturally other is, Bernasconi notes, only conceived in a single direction, limiting the responsibility and by implication the humanity of those others (Bernasconi 1992, 22) and Caygill observes similar ambivalences in relation to Islam, Arab nationalism and Palestine (Caygill 2002).

To be clear, these are controversial and much debated problems in Levinas's philosophy; they are not Biesta's problems and The Beautiful Risk is not obliged to resolve nor even address them. Given Biesta's central role in introducing the philosophy of Levinas to educational theory he is no doubt aware of these criticisms of Levinas, as well as of the large number of nuanced responses that seek to acknowledge and overcome them (cf. Drabinski, 2011, etc.). It is therefore likely that Biesta's passing over of these debates in silence (perhaps even in that 'language without teaching, a silent language' that Levinas $(1979,155)$ associated not with transcendence but feminine familiarity) marks a commitment to a different, more affirmative understanding of how we are to read and relate to difficult philosophical writings, one that in his own words 'attempts to respond to the saying that is beyond what is said... and that does so in a responsible manner' (Biesta 2003, 64). This is how he approaches John Dewey's pragmatism in the book's second chapter, when Biesta raises the problem of the Western, naturalistic, and secular assumptions of Dewey's account of communication as a barrier to facilitating communication among those who do not share such a worldview, and responds by insisting, with Derrida, that 'we must be prepared to take the risk that this philosophy will change as a result of our entering this philosophy in our communication with others' (40-1). Indeed, he characterizes such an approach to reading or learning from philosophy as 'first and foremost a pedagogical question ...perhaps ...even the ultimate pedagogical question.'

My purpose in raising some of the problems that have troubled the reception of Levinas's philosophy is, therefore, not to "school" Biesta on the correct interpretation of Levinas's philosophy (I remain an ignorant schoolmaster in this respect) but to ask (like a good student?) how this issue of the responsibility or irresponsibility of 'learning from' relates to the earlier question of whether we are making education riskier or safer when we teach - or don't 
teach - such philosophical conflicts. Does this uncritical, or at least unreflective, use of Levinas risk teaching a sanitized or risk-free version of Levinas's thought or does it avoid the risk?

\section{A Theology or a Politics of Education?}

At this point it is important to reiterate that Biesta challenges any understanding of the transcendence in Levinas's encounter with otherness that reduces it to a 'specific, embodied individual ...a human other' (49). Consequently, thinking transcendence in terms of the 'possibility that something more radically different might break through' within education should involve 'more than only the otherness of other human beings' (49). For, 'as soon as one brings transcendence in, one has to take it seriously all the way down - or perhaps we should all the way "up" (56). Teachings, for Biesta, ultimately come not from the relationship with a teacher but an encounter with something akin to the mysterious God of the Bible (as opposed to the rational God of Philosophy) and experienced as the revelation of that which absolutely transcends philosophical thought.

This not only distinguishes the different relations to transcendence, otherness and sacrifice involved in Biesta's and Todd's distinct accounts of the beautiful risk of education, but may help in avoiding the problematically gendered, sexualized and Westernized perspective upon the Other which trouble aspects of Levinas's philosophy. Since this version of alterity involves a rethinking of transcendence as something radically different than the human $-\mathrm{a}$ revelation of something beyond human cognition, comprehension and being - the normative perspective of the subject that encounters such difference is a more generically human one.

Even if feminist and postcolonial philosophers might question the validity of this move, which risks not transcending the normative but universalizing it, there is nonetheless a danger that some of the resources The Beautiful Risk utilizes to radicalize Levinas in this way end up reasserting, rather than moving beyond, these issues. The account of educational subjectification developed in the first chapter on creativity derives from the Christian theologian Caputo's (2006) deconstructive reading of the book of Genesis, for example, and that of transcendence in the third chapter derives from the Christian philosopher Merold Westphal's (2008) description of transcendence in the existentialism of Kierkegaard and Levinas.

It is interesting, however, that these theological sources (and Levinas's ethics more generally) drop away as the book unfolds, suggesting a shift from a theologically-grounded ethics to a politics of education, as Biesta draws instead upon the work of Foucault, Rancière and Arendt. Some might ask whether the humanizing impulse that follows from Biesta's more 
radical notion of transcendence can ultimately cohere with practical political struggle or conflict (this also accounts for the tense relationship between ethics and politics in Levinas's philosophy, cf. Caygill 2002), but if Biesta is able to maintain some kind of political theology it is by objecting that such criticism makes the mistake of demanding a strong - rather than weak - conception of the political: not as the necessary preparation for a democracy yet to come but politics (in an Arendtian sense) as participation in a community involving common action and imagination which enables us to bridge the abyss to others; a community, moreover, that is enacted as the starting point of education (in a Rancièrean sense) and not promised as its outcome.

In this political context, it may be significant that when Biesta identifies what he calls the strong Enlightenment account of emancipation with the Marxist tradition of ideology, he does so by characterizing the latter's account as requiring 'an intervention from the "outside" ...by someone who is not subjected to the power that needs to be overcome' (82). Perhaps the most famous theory of ideology in this tradition - certainly one Rancière takes issue with - is that of Althusser, whose own account of interpellation as subjectification mirrors and rivals that of Levinas (cf. Oliver 2001, 180). In this context, Althusser's example of God's call and Moses's answer - "It is (indeed) I!" - must ground the impossible - ideological - origination of individuals as "always already" subjects. Since this call must be ultimately projected from a position of radical alterity, Althusser invokes God as both 'the Subject par excellence' (the primal Subject) and 'an Other Subject, Unique and central' (what we might call the unsubjected Subject).

Consequently, for Althusser it is subjectification itself that is founded on an intervention from the "outside" by some one - God - who is not subjected to the power that needs to be overcome. In contrast, Althusser's appeal to what Biesta calls emancipation doesn't emphasise the necessity of some one else (for all subjects are ideological subjects according to Althusser's antihumanism) but precisely some thing else: the proclaimed subjectless position of Marxist Philosophy (cf. Althusser 2001, 116). The shift from some thing to some one in Biesta's description perhaps risks occluding the structural proximity of and ultimate divergence in these two accounts of subjectification (reversing this move, on the other hand, perhaps too crudely establishes the alternative educational positions in Althusser's and Levinas's writings: Philosophy versus God).

While The Beautiful Risk sets out from the theological recovery of a weak God (and this would seem to mark and perhaps anticipate its continuity with a certain strand of neoKantianism), the second half of the book, in its concern with a weak version of political 
philosophy, seems to approach from the other direction. This is not to say these various perspectives cannot be reconciled (or even that they have to be) but, again, simply to raise the question of whether or not Biesta's writing risks communicating this.

\section{The Truant Teacher?}

This returns us to the question of what is risked or not risked in Biesta's notions of weak and strong education. A strong education that is secure, risk-free and predictable is problematic, Biesta argues, precisely because, 'education is not an interaction between robots but an encounter between human beings' (1), 'a perfect match between "input" and "output,", characteristic of instruments, 'is neither possible or desirable' (1), 'education always deals with living "material," that is, with human subjects, not with inanimate objects' (2), 'education necessarily needs to have an orientation toward the freedom and independence of those being educated' (2), and because 'the educational way ... may well turn out to be the only sustainable way, since we all know that systems aimed at the total control of what human beings do and think eventually collapse under their own weight...' (4).

This defence of freedom and spontaneity against educational instrumentalism will resonate with educational theorists and teachers alike, and it is not necessary to accept the conception of the living, human subject that Biesta derives from Levinas to be persuaded by these claims (although the absence of traditional Marxist and feminist accounts of economic and sexual - as well as intellectual - inequality might provide more compelling clues to the motivations underlying such control). However, while the book's characterization of the problem of strong education resonates with much of the dialogue around current educational discourse and policy, it is sometimes difficult to identify who would promote the (problematically) strong versions of the educational topics explored and therefore how these intersect with the broader trend towards strong education introduced at the outset.

In the first chapter on creation, for example, Biesta claims that a strong version of creation is contentious in part because it is grounded in a strong metaphysical sense of an omnipotent creator, creating ex nihil. If we think of creation in this way, he adds, 'then the idea that we as educators create our students doesn't make any sense at all' (19). The choice should therefore be not between creationism or its rejection, Biesta insists, but rather between educational versions of a strong metaphysical creationism - which brings into being out of nothingness - and a weak existential creationism, where creation is an event through which existing being is transformed into moral life by being gifted significance and meaning. The fact that this strong version of creation makes little sense in educational terms implies that his 
elucidation of a weak educational creationism responds to the problem not of strong creationism itself but of a dominant anti-creationist prejudice, or the disavowal of what Biesta terms subjectification within education altogether. In other words, the attempt to make education strong, safe and risk-free would, on this account, seem to involve the rejection of both strong and weak creationism.

Biesta's criticism of strong creationism is therefore intended to clear a space for the recovery of creationism in its weak sense and a great virtue of the discussions of communication and teaching is that they proceed in a similarly nuanced vein. As a consequence of this, however, an ambiguity remains over the relation between, on the one hand, the strong versions of creation, teaching, emancipation and others topics discussed and, on the other hand, the overarching criticism of the demand for education to be strong and risk-free, which Biesta attributes to policy makers, politicians, the popular press, "the public," and organizations such as the OECD and World Bank. Is strong education problematic because it is constituted by creation, communication or emancipation in their strong senses - that is, the expectation of omnipotent teachers producing subjects, the 'transmission of information from one person to another ... without transformation or distortion' (26), teaching as a gift 'that lies in the power of the teacher to give' (44), 'emancipation ...ultimately contingent upon the truth about our objective condition, a truth that can only be generated by someone else who is positioned outside of the influence of ideology'? Or is it problematic precisely because it 'seeks the demise of the teacher as someone who has something to say and something to bring' (56) - a position attributed to the dominant constructivism of Glaserfled, Piaget, Vygotsky and Dewey in Biesta's discussion of "learnification" in the other chapters - and so is against even weak creation, weak communication, weak teaching and weak emancipation?

We are taught to ask questions by raising our hands; Biesta advocates a pedagogy of interruption. If this review cannot escape the contradictions of a certain kind of double bind (cf. Spivak 2012, 3-4) in responding to Biesta's work, this is ultimately because, caught between the conflicting positions of the student and the master, it cannot adopt the position of the truant child but only that of the truant teacher, peering through the window upon the scene of teaching taking place within. Ultimately, though, perhaps what we observe in The Beautiful Risk of Education is less a seminar classroom than a dojo, where teachers must learn to practice their art empty-handed and education's greatest strength lies in its weakness and flexibility. Biesta's theory of the advantage of weakness in education seems to depend, as in certain martial arts, upon the presumed strength of the Other. On these inverted terms, the success of Biesta's 
writing can be judged according to a compelling expositional "weakness," while there are further questions to be asked about what kind of risks this might involve.

\section{References}

Althusser, L. 2001. Lenin and Philosophy and other essays. New York: Monthly Review Press. Beauvoir, S. de. 2010. The Second Sex. Translated by C. Borde and S. Malovany-Chevallier, New York: Alfred A. Knopf.

Bernasconi, R. 1992. "Who is My Neighbor? Who is the Other? Questioning 'the Generosity of Western Thought'". In Ethics and Responsibility in the Phenomenological Tradition (Ninth Annual Symposium of the Simon Silverman Phenomenology Center), 1-31. Pittsburgh: Duquesne University Press.

Biesta, G. J. J. 2003. "Learning from Levinas: A Response". Studies in Philosophy and Education 22 (1): 61-68.

Biesta, G. J. J. 2006. Beyond Learning: Democratic education for a human future. Boulder, CO: Paradigm Publishers.

Biesta, G. J. J. 2010a. Good Education in an age of Measurement: Ethics, politics, democracy. Boulder, CO: Paradigm Publishers.

Biesta, G. J. J. 2013. The Beautiful risk of Education. Boulder, CO: Paradigm Publishers.

Biesta, G. J. J. 2015a. "The Rediscovery of Teaching: On robot vacuum cleaners, nonegological education and the limits of the hermeneutical world view". Educational Philosophy and Theory. Advance online publication. doi: 10.1080/00131857.2015.1041442

Biesta, G. J. J. 2015b. "Teaching, Teacher Education, and the Humanities: Reconsidering Education as a Geisteswissenschaft". Educational Theory 65 (6): 665-679.

Biesta, G. J. J., and C. Bingham. 2010. Jacques Rancière: Education, Truth, Emancipation. London: Continuum.

Caputo, J. D. 2006. The Weakness of God: A Theology of the Event. Bloomington, IN: Indiana University Press.

Caygill, H. 2002. Levinas and the Political. London: Routledge.

Chalier, C. 1982. Figures du féminin. Paris: La nuit surveillée.

Drabinski, J. E. 2011. Levinas and the Postcolonial: Race, Nation, Other. Edinburgh: Edinburgh University Press.

Levinas, E. 1998. Otherwise than Being, or, Beyond Essence. Translated by Alphonso Lingis. Pittsburgh: Duquesne University Press. 
Levinas, E. 1979. Totality and Infinity: An Essay on Exteriority. Translated by Alphonso Lingis. The Hague: Matinus Nijhoff Publishers.

Levinas, E. 1987a. "Meaning and Sense". In Collected Philosophical Papers. Translated Alphonso Lingis. The Hague: Matinus Nijhoff Publishers.

Levinas, E. 1987b. Time and the Other. Pittsburgh, PA: Duquesne University Press.

Levinas, E. 1991. "Jewish Thought Today". In Difficult Freedom: Essays on Judaism. Translated Seán Hand, 159-166. London: Athlone Press.

McGettigan, A. 2006a. "Disputes in the 'metaphysics' of ethico-political transformation: a reassessment of the speculative philosophies of Jacques Derrida and Emmanuel Levinas". PhD diss., Middlesex University.

McGettigan, A. 2006b. "The philosopher's fear of alterity: Levinas, Europe and humanities 'without Sacred History"”. Radical Philosophy 140: 15-25.

Oliver, K. 2001. Witnessing: Beyond Recognition. Minneapolis: University of Minnesota Press.

Sanford, S. 2000. The Metaphysics of Love. London: Althone Press.

Spivak, G. C. 1993. Outside in the Teaching Machine. New York: Routledge.

Spivak, G. C. 2012. An Aesthetic Education in the Era of Globalization. Cambridge, MA: Harvard University Press.

Todd, S. 2003a. "A Fine Risk to be Run? The Ambiguity of Eros and Teacher Responsibility". Studies in Philosophy and Education 22 (1): 31-44.

Todd, S. 2003b. Learning from the Other: Levinas, Psychoanalysis, and Ethical Possibilities. New York: SUNY.

Westphal, M. 2008. Levinas and Kierkegaard in dialogue. Bloomington, IN: Indiana University Press.

${ }^{1}$ I would like to thank Emile Bojesen and Andrew McGettigan for their comments on an earlier version of this review. 